Chirurgia (2021) 116: 331-338

No. 3, May-June

Copyright@ Celsius

http://dx.doi.org/10.21614/chirurgia.116.3.331

\title{
Is Colorectal Cancer Stage Affected by COVID-19 Pandemic?
}

\author{
Radosav S. Radulovic ${ }^{*}$, Vladica V. Cuk ${ }^{1,2}$, Jovan T. Juloski ${ }^{1,2}$, Dragana D. Arbutina', Igor D. Krdžic ${ }^{1,2}$, \\ Ljiljana V. Milic ${ }^{1,2}$, Marko V. Kenic ${ }^{1,2}$, Aleksandar R. Karamarkovic ${ }^{1,2}$
}

'Surgical Clinic "Nikola Spasic", University Clinical Center "Zvezdara", Belgrade, Belgrade, Serbia

${ }^{2}$ Surgery Department, Faculty of Medicine, University of Belgrade, Serbia

*Corresponding author: Radosav S. Radulovic, MD

Surgical Clinic "Nikola Spasic"

Zvezdara University Medical Center

Dimitrija Tucovica Street 161

11120 Belgrade, Serbia

E-mail: raderadulovic89@gmail.com

\section{Rezumat}

Stadiul cancerului colorectal este afectat de pandemia COVID-19?

Context: Pandemia COVID-19 influențează în mod semnificativ evolutia pacienților cu cancer colorectal prin suprasolicitarea sistemelor de sănătate. Scopul acestui studiu este de a evalua impactul pandemiei COVID-19 asupra stadiului în care este diagnosticat cancerul colorectal.

Material şi Metodă: Acest studiu este de tip retrospectiv şi evaluează comparativ două grupuri de pacienți operați pentru cancer colorectal în Clinica de Chirurgie „Nikola Spasic”, Centrul Medical al Universității Zvezdara. Grupul de studiu a fost format din 49 de pacienți operați în perioada 15 martie 2020 - aprilie 2021 , in timpul pandemiei. Grupul de control a fost format din 152 de pacienți, operați în perioada 01 ianuarie 2019 - 31 decembrie 2019. Rezultate: În acest studiu nu au fost identificate diferențe între grupurile analizate în ceea ce priveşte abordarea chirurgicală, practicarea stomiilor, procentul complicațiilor postoperatorii şi rata respitalizării. Stadiul T4b al tumorilor colorectale a fost statistic semnificativ mai frecvent întâlnit în grupul de studiu ( $12,2 \%$ vs $3,3 \%, p=0,027)$. De asemenea, tumorile invazive local, stadiu IIC, au fost semnificativ mai frecvent întâlnite în grupul studiat $(10,2 \%$ vs $1,3 \%, \mathrm{p}=0,01)$.

Concluzie: Impactul pandemiei COVID-19 asupra sistemului de sănătate ar putea explica numărul crescut de tumori în stadii avansate local identificate în grupul de pacienți studiat.

Cuvinte cheie: cancer colorectal, COVID-19, stadiul cancerului 


\section{Abstract}

Background: Causing healthcare systems overload, COVID-19 pandemic has a huge influence on patients with colorectal cancer. The aim of our study was to assess the potential impact of COVID-19 on the stage of colorectal cancer.

Methods: In our retrospective study, two groups of patients operated for colorectal cancer were analyzed at the Clinic for Surgery "Nikola Spasic", Zvezdara University Medical Center. The study group consisted of 49 patients operated in the period from March 15, 2020 to April 2021, during COVID-19 pandemic. The control group consisted of 152 patients, who were operated on in the period from January 1, 2019. to December 31, 2019.

Results: There were no difference in surgical approach, prevalence of stoma, percentages of postoperative complications and rates of hospital readmission between both groups. T4b tumor stage was statistically significant more common in the study group $(12.2 \%$ vs $3.3 \%, \mathrm{p}=0.027)$. Locally advanced tumors, stage IIC, were statistically significantly more common in the group of patients operated on during the COVID-19 pandemic ( $10.2 \%$ vs $1.3 \%, \mathrm{p}=0.01)$.

Conclusion: Higher number of locally advanced tumors in study group could probably be caused by the impact of the COVID-19 pandemic on healthcare system.

Key words: colorectal cancer, COVID-19, cancer stage

\section{Introduction}

A new type corona virus, SARS-CoV-2, appeared in December 2019 in the Chinese province of Huabei, and then spread to the rest of the world. The World Health Organization has declared COVID 19 a public health emergency of international concern January 30, and the pandemic on March 11, 2020 (1). The first case of SARS-CoV-2 virus in Serbia was recorded on March 6, 2020. Ten days later, an epidemic was declared, after which numerous institutions were turned into COVID hospitals on several occasions, including our institution, the Clinic for Surgery of the Clinical Hospital Center Zvezdara.

The pandemic caused by the SARS-CoV-2 virus is a major blow to health systems around the world, and especially to vulnerable groups of patients such as those suffering from malignancy. The COVID-19 pandemic has dramatic effects on the entire aspect of screening, diagnosis, treatment and follow-up of cancer patients $(2,3)$. The influx of large numbers of COVID-19 patients requiring intensive monitoring and mechanical ventilation has resulted in overloading of health systems in affected regions, disrupting the usual treatment of oncology patients, who form a particularly vulnerable population, and whose results are likely to be adversely affected by delayed standard treatment (4).

Colorectal cancer is the fourth most common cancer and the second most common cause of cancer death globally (5). The age-standardized global incidence of colorectal cancer in 2018 was $19.7 / 100,000$, higher in men than in women (23.6/100,000 vs. $16.3 / 100,000)$ (6).

Colorectal cancer is also a significant cause of morbidity and mortality in Serbia. According to GLOBOCAN, the number of new cases in 2018 was 6049 (12.6\% of any form of cancer), as well as the cause of 3187 deaths $(2.9 \%$ of all cancer-related deaths) (7).

Based on the literature to date, the best results in the treatment of colorectal cancer are achieved in tumors diagnosed in the early stages of the disease $(8,9)$, and any delay in diagnosis and treatment is associated with disease progression resulting in poorer treatment outcome (10). Current guides recommend a short interval from symptoms to diagnosis, with a standard of initiating treatment within six weeks of diagnosis for $90 \%$ of patients (11). 
The aim of our study was to assess the potential impact of the COVID-19 pandemic on the stage of colorectal cancer in Serbian population.

\section{Material and Methods}

In our retrospective study, two groups of patients operated for colorectal cancer were analyzed at the Clinic for Surgery "Nikola Spasic", Clinical Hospital Center Zvezdara.

The control group consisted of 152 patients, who were operated on in the period from January 1, 2019. to December 31, 2019, before the COVID-19 pandemic in Serbia. The study group consisted of 49 patients operated on between epidemic waves, in the period from March 15, 2020 to April 2021, when our institution was not in the COVID-19 system of work.

Including criteria were all patients older than 18 years, both genders, who underwent elective/emergency, that is classical/laparoscopic resection due to colorectal cancer. Patients in whom only derivational stoma was performed due to colorectal cancer were excluded from the study, as well as operated patients with a complete response to neoadjuvant chemoradiotherapy. The condition for admission of patients of the study group to the hospital was a negative PCR test for SARS-CoV-2 virus, in addition, a serological test for SARS-CoV-2 virus was performed on the day of surgery, and it had to be negative. For laparoscopic approach, wie used device for evacuation of smoke and KN 95 masks.

\section{Statistical Analysis}

The data were extracted from the hospital information system "HELIANT" and processed in the statistical program IBM SPSS Statistics 25. $\mathrm{P}<0.05$ indicated a statistically significant difference in this study. The study analyzed the average age of the patient, the prevalence of different localizations of colorectal cancer, type of surgery, TNM, modified Astler-Coller classification, stage of disease, length of postoperative treatment, Clavien-Dindo scale of postoperative complications, rehospitalization within 30 days of discharge.

\section{Results}

Of the 152 patients in the control group, 65 were women (42.8\%) and 87 men (57.2\%), while in the study group of 49 patients there were 27 women (55.1\%) and 22 men (44.9\%). The mean age of the patients in the control group was $67.11 \pm 11.621$, while in the study group it was $67.41 \pm 10.378$.

The most common tumor localizations in both groups were rectum (in the control group $26.97 \%$, in the study group $26.5 \%$ ) and sigmoid colon (in the control group $25.66 \%$, while in the study group it is $24.6 \%$ ). The rarest localization of cancer in both groups was the appendix. Table 1 shows the percentage of tumors of different localizations in the control and study group.

Right hemicolectomy was the most common operation performed in both groups of patients, in the control group 41 patients underwent right hemicolectomy, which accounts for $27 \%$ of all types of operations, while in the study group, 16 patients underwent right hemicolectomy, which represents $32.7 \%$ of all operations. Table 2 shows the number and percentage of different types of operations.

Regarding the operative approach in the control group of patients, 36 laparoscopic colorectal resections were performed, which

Table 1. Different localizations of tumors in the control and study group

\begin{tabular}{lccc}
\hline Tumor localization & \multicolumn{2}{c}{ Group } & Total \\
\hline Appendix & Study No (\%) & Control No (\%) \\
\hline Cecum & $0(0)$ & $1(0.66)$ & 1 \\
\hline Ascedent colon & $4(8.2)$ & $16(10.53)$ & 20 \\
\hline Hepatic flexure & $7(14.3)$ & $10(6.58)$ & 17 \\
\hline Transversal colon & $2(4.1)$ & $8(5.26)$ & 10 \\
\hline Lienal flexure & $5(10.2)$ & $7(4.61)$ & 12 \\
\hline Descedent colon & $3(6.1)$ & $9(5.92)$ & 12 \\
\hline Sigmoid colon & $1(2)$ & $7(4,61)$ & 8 \\
\hline Rectosigmoid junction & $12(24.5)$ & $39(25.66)$ & 51 \\
\hline Rectum & $2(4.1)$ & $14(9.21)$ & 16 \\
\hline Total & $13(26,5)$ & $41(26,97)$ & 54 \\
\hline
\end{tabular}


Table 2. Number and percentage of different types of operations

\begin{tabular}{lccc}
\hline Type of surgery & \multicolumn{2}{c}{ Group } & Total \\
\hline & Study No (\%) & Control No (\%) & \\
\hline Right hemicolectomy & $16(32.7)$ & $41(27)$ & 57 \\
\hline Left hemicolectomy & $4(8.2)$ & $36(23.7)$ & 40 \\
\hline PME & $9(18.4)$ & $23(15.1)$ & 32 \\
\hline TME & $11(22.4)$ & $34(22.4)$ & 45 \\
\hline Abdominoperineal resection & $3(6.1)$ & $6(2.6)$ & 9 \\
\hline Subtotal colectomy & $1(2)$ & $4(2.6)$ & 5 \\
\hline Total colectomy & $1(2)$ & $2(1,3)$ & 3 \\
\hline Partial colon resection & $4(8.2)$ & $6(3.9)$ & 10 \\
\hline Total & 49 & 152 & 201 \\
\hline
\end{tabular}

represents $23.7 \%$, while a quarter of the patients $(26.5 \%)$ of the study group underwent laparoscopic approach.

In the study group, in $26.5 \%$ of patients, the operation was completed by creating a terminal stoma, while in the control group, that percentage was $21.7 \%$. Using the Z-test $(\mathrm{p}=0.242)$, no statistically significant difference was observed between these two groups.

The mean postoperative hospital stay in the study group was $9.58 \pm 3.64$ days, while in the control group it was $10.77 \pm 6.09$ days. Regarding postoperative complications expressed through Clavian-Dindo classification, there was no statistically significant difference between the control and study group of patients. There was also no statistical significance in readmission hospital rates in the interval of 30 days from discharge $(8.2 \%$ in the study group, $5.9 \%$ in the control group, $\mathrm{p}=0.39$ ).

We analyzed and compared the proportions of different $\mathrm{T}$ stages in both groups (Graph 1). $\mathrm{T} 1$ stage was represented by $4.1 \%$ in the study group, while in the control group it was represented by $7.3 \%$, there was no statistically significant difference in percentage of $\mathrm{T} 1$ stage between the study and control group $(\mathrm{p}=0.34)$. T2 stage accounted for $20.4 \%$ in the study group, while in the control group it accounted for $17.9 \%$, we didn't find statistically significant difference in distribution of T2 stage between analyses groups $(p=0.41)$. In both groups, the most common was the T3 stage (59.2\% in the study group, $69.5 \%$ in the control group, $p=0.12$ ). T4a stage was represented in the study group of patients with $4.1 \%$, while the control group was represented with $2 \%$, there was no statistically significant difference between the study and control group of patients in distribution of T4a stage $(p=0,36)$.

The incidence of $\mathrm{T} 4 \mathrm{~b}$ stage tumors in the control group was $3.3 \%$, while in the study group it was $12.2 \%$ and using Fisher's exact test, a statistically significant difference ( $p 0.027<0.05$ ) was observed in the percentage of T4b stage between treated patients. before the COVID-19 pandemic and patients treated between the two waves of the COVID-19 pandemic.

The average number of isolated lymph nodes in the study group of patients was 18.32 \pm 9.23 , while in the control group it was 17.93 \pm 10.16 . We analyzed the percentage of different $\mathrm{N}$ stages in the control and study group (Graph 2). In both groups of patients, the most common was the No stage (in the
Graph 1. Distribution of different $T$ stages in both groups

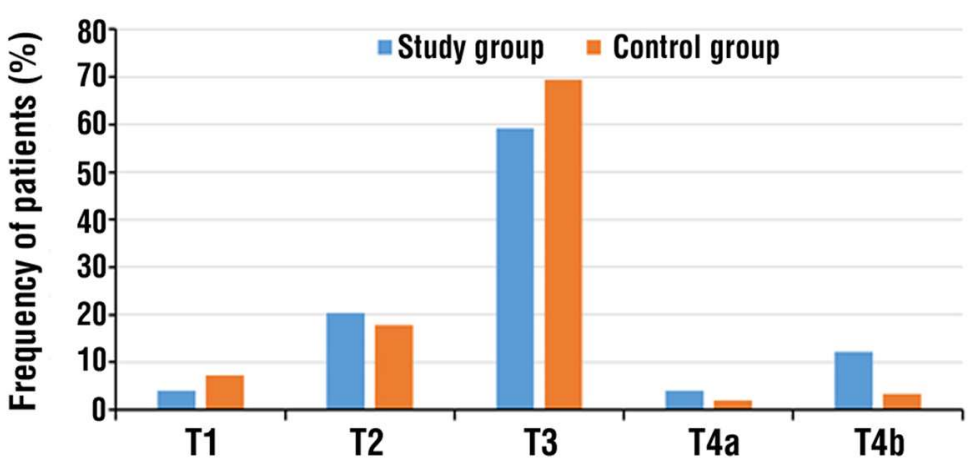

www.revistachirurgia.ro

Chirurgia, 116 (3), 2021 
Graph 2. Distribution of different $\mathrm{N}$ stages in both groups

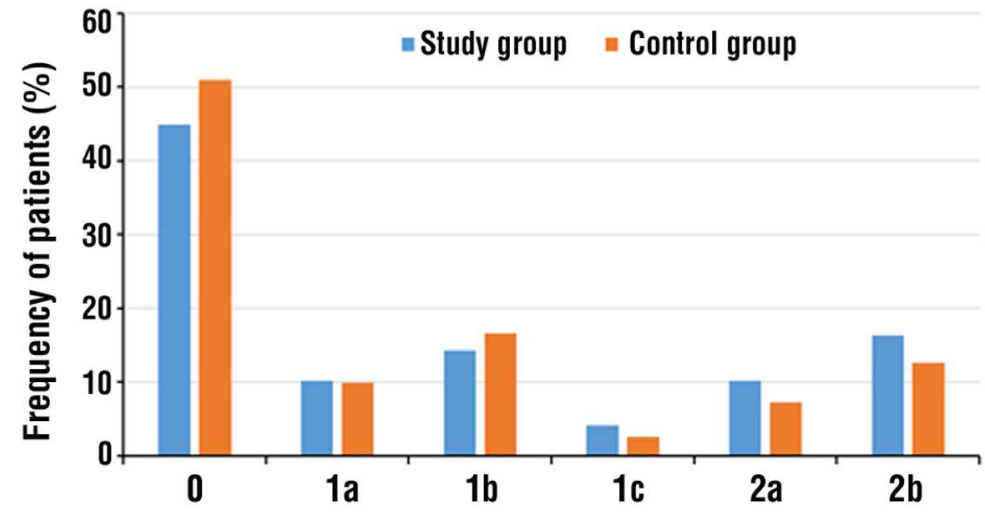

control group $51 \%$, in the study group $44.9 \%$, $\mathrm{p}=0.28$ ). No statistically significant difference in the representation of different $\mathrm{N}$ stages between the control and study group was found.

Regarding the $\mathrm{M}$ stage of the disease in both groups of patients, the most common was the M0 stage $(92.1 \%$ in the control group, $85.7 \%$ in the study group, $p=0.12$ ). Despite the fact that the M1a stage was twice as common in the study group compared to the control group ( $14.2 \%$ vs $7.9 \%, \mathrm{p}=0.15)$, we did not find a statistically significant difference in the representation of different M1 stages between these groups.

We analyzed distribution of tumor stages in the control and study group (Table 3, Graph 3). Using Fisher's exact test, we found a statistically significant difference $(p=0.033$ $<0.05$ ) in the prevalence of stage IIA between the control (27.6\%) and study group of
Table 3. Distribution of colorectal carcinoma stages in both groups

\begin{tabular}{lccc}
\hline Stage of disease & \multicolumn{2}{c}{ Group } & Total \\
\hline Study No (\%) & Control No (\%) & \\
\hline IIA & $9(18.4)$ & $29(19.1)$ & 38 \\
\hline IIB & $6(12.2)$ & $42(27.6)$ & 48 \\
\hline IIC & $1(2)$ & $2(1.3)$ & 3 \\
\hline IIIA & $5(10.2)$ & $2(1.3)$ & 7 \\
\hline IIIB & $3(6.1)$ & $8(5.3)$ & 11 \\
\hline IIC & $13(26.5)$ & $42(27.6)$ & 55 \\
\hline IVA & $5(10.2)$ & $15(9.9)$ & 20 \\
\hline IVB & $6(12.2)$ & $9(5.9)$ & 15 \\
\hline IVC & $1(2)$ & $2(1.3)$ & 3 \\
\hline Total & $0(0)$ & $1(0.7)$ & 1 \\
\hline
\end{tabular}

patients (12.2\%). Also, using Fisher 's exact test, we showed that there is a statistically significant difference $(p=0.01<0.05)$ in the prevalence of stage IIC between the control $(1.3 \%)$ and study (10.2\%) group of patients. We also used the $\mathrm{Z}$ test to determine the existence
Graph 3. Distribution of different colorectal cancer stages in both groups

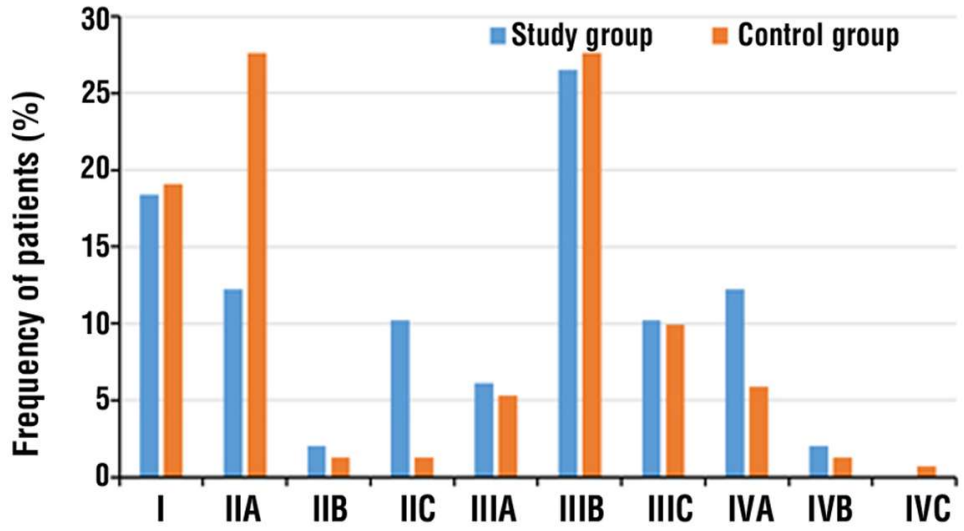

Chirurgia, 116 (3), 2021 
Graph 4. Distribution of the different modified Astler-Coller stages in both groups

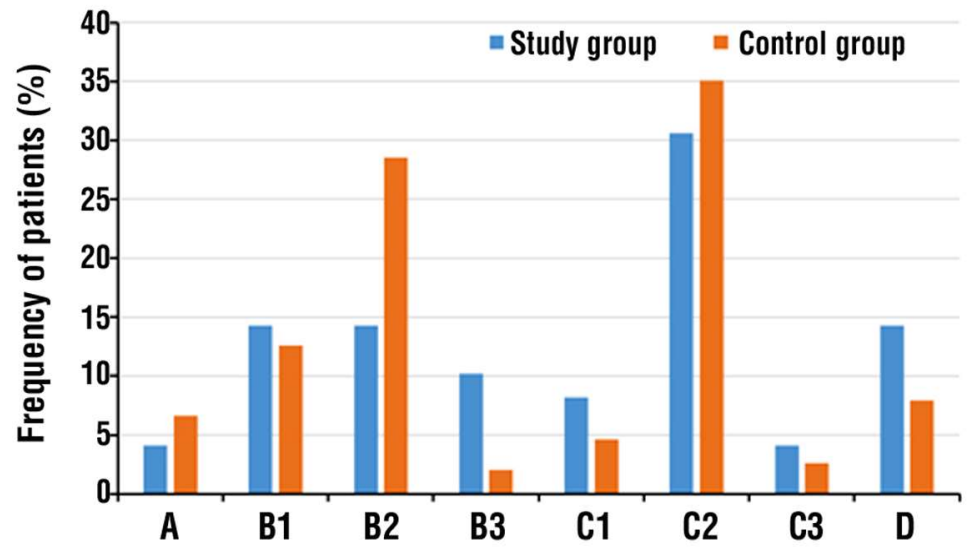

of a statistically significant difference $(p=0.023$ $<0.05$ ) in the prevalence of B2 stage tumors of the modified Astler-Coller classification between the control (28.5\%) and study group (14.3\%) patients, while using Fisher's exact test, we found a statistically significant difference $(p=0.02<0.05)$ in the representation of the B3 stage of the modified Astler-Coller classification between the control $(2 \%)$ and study group (10.2\%) (Graph $\downarrow$ ).

In terms of tumor differentiation, there was no statistically significant difference between the control and study groups of patients. In both groups of patients, the most common were moderately differentiated G2 tumors (67.8\% in the control group, $62.5 \%$ in the study group).

\section{Discussion}

The COVID-19 pandemic has brought numerous challenges in the treatment of patients with colorectal cancer. The pressure on health systems has resulted in a reduction in the number of endoscopic procedures within screening and diagnostics (12), as well as a reduction in the number of elective operations. In such circumstances, there is a need to protect healthcare professionals and patients from SARS-CoV-2 infection, given the existence of evidence that the development of symptomatic infection during the perioperative period is associated with very high mortality and morbidity $>20 \%$ (13).
Morris et al. in its population based study conducted in England, states that in April 2020, at the height of the COVID-19 pandemic, there was a relative reduction in the number of colorectal cancer operations by $31 \%$ compared to the monthly average of such operations during 2019 (1378 operated vs. 2003 operated) (12). The results of other studies show such a trend of reduced colorectal cancer surgery (14, 15). Preliminary results based on unpublished data suggest the three time decrease in number of colorectal cancer operations in our institution during COVID-19 pandemic in our country.

There is much controversy about the safety of laparoscopic surgery during the COVID-19 pandemic. Namely, the virus was found in peritoneal fluid in high concentration (16). Laparoscopic surgery requires the creation and maintenance of pneumoperitoneum through $\mathrm{CO} 2$ insufflation, thus carrying the risk of aerosol exposure. Aerosol exposure occurs with the intentional or unintentional release of $\mathrm{CO} 2$, most commonly during port placement and removal, instrument insertion and removal, specimen extraction, and pneumoperitoneum removal at the end of surgery (17). Fear of aerosol transmission of the SARSCoV-2 virus has influenced the need to examine the safety of laparoscopic surgery during the COVID-19 pandemic. Since there is no solid scientific evidence in the literature to date on virus transmission during laparoscopic surgery, we have continued with laparoscopic 
colorectal cancer surgery during a pandemic with increased precautions, according previous trends in treatment of patients with colorectal cancer in our hospital. The results of our study indicate that there is no significant difference in surgical approach between patients operated on during and before the COVID-19 pandemic. Some researchers also noted that there was no difference in the prevalence of the laparoscopic approach before and during the pandemic (14), while others reported that the number of laparoscopic operations for colorectal cancer decreased during COVID-19 pandemic (15).

Since there are data suggesting that cancer patients are at higher risk of SARS-CoV-2 infection and more prone to a worse outcome $(18,19)$, some recommendations favor the use of less risky procedures (stoma vs colorectal anastomosis) to reduce the possibility of complications requiring recovery in intensive care units (20). In our study, there was no significant difference in the percentage of terminal stoma between the control and study group ( $21.7 \%$ vs. $26.5 \%, p=0.242)$, noting that we did not consider the frequency of protective stoma in the study. Some authors observed an increased incidence of stoma within colorectal cancer resections during the COVID-19 pandemic $(12,14,21)$, while other authors present results indicating no difference in stoma involvement within colorectal resections before and during the COVID-19 pandemic (20).

Postoperative complications are associated with a poor long-term outcome and significantly affect the quality of life of patients (22). Severe postoperative complications resulting from even elective colorectal surgery may require reoperation, some authors state that the estimated relaparotomy in elective resections performed for colorectal cancer is up to $7.2 \%$ (23). Using the Clavien-Dindo classification, we analyzed the incidence of complications in the control and study group of patients, there was no statistically significant difference in the prevalence of severe post-operative complications (Clavien-Dindo III, IV, V) between the observed groups of patients (control group 5.2\%, study group $8 \%$, $\mathrm{p}=0.33$ ), as indicated by the results of other studies $(14,15,20,21)$.

The impact of the COVID-19 pandemic on the stage of colorectal cancer is still being considered. The results of a prospective study of patients with colorectal cancer operated on at Asan Medical Center, Seoul, South Korea, between March and September 2020, do not show a significant difference in the distribution of TMN stages between patients operated on during and before the COVID-19 pandemic (15).

Cui et al (14), in a design study similar to ours, also presents results indicating that there was no difference in TMN stage distribution between the group of patients operated on for colorectal cancer during and the group operated before the COVID-19 pandemic. Increased incidence of advanced stages ( $\mathrm{T} 4, \mathrm{cN}+$, or $\mathrm{M} 1)$ of newly diagnosed cases of colorectal cancer in the period from March 1 to July 31, 2020 compared to the same period in 2019 (38.7\% vs. $64 \%)$ observed in one observational cross-sectional comparative analysis of AC Camargo Cancer Center, Sao Paulo, Brazil (24).

In our study, we observed a higher prevalence of stage II disease in the control group of patients compared to the study group $(30.2 \%$ vs $24.2 \%)$. Further analysis showed that stage IIA (T3N0) was statistically more prevalent $(27.6 \%$ vs $12.2 \%, \mathrm{p}=0.033)$ in patients operated on for colorectal cancer in the period before the COVID-19 pandemic, while locally advanced tumors, Stage IIC, were statistically significantly more common in the group of patients operated on during the COVID-19 pandemic ( $10.2 \%$ vs. $1.3 \%$, $\mathrm{p}=0.01)$. We also observed a higher prevalence of metastatic disease in the study group of patients compared to the control ( $14.2 \%$ vs $7.9 \%$ ), but further analysis did not determine the existence of statistical significance, $p=0.5$. We explain our results with delayed diagnostics and more restrictive hospital admissions due to the overload of the health system. 


\section{Conclusion}

Our results showed higher number of locally advanced tumors in operated patients during the COVID-19 pandemic than before the pandemic. This could probably be due to the delay in treatment caused by the COVID-19 pandemic and its impact on healthcare system. Even though in group of patients operated during COVID 19 pandemic was more patients with metastatic disease, we did not show statistical significance difference between two groups. Another more studies with more patients should be taken, for assessment of affects of COVID 19 pandemic on stages presentation of colorectal cancer.

\section{Conflicts of Interest and Source of Funding}

The authors declare no conflicts of interests. This study did not receive any financial support.

\section{Ethics of Approval}

For performing this study ethical approval was obtained.

\section{Reference}

1. Balkhair AA. COVID-19 Pandemic: A New Chapter in the History of Infectious Diseases. Oman Med J. 2020;35(2):e123.

2. Chan A, Ashbury F, Fitch MI, Koczwara B, Chan RJ. Cancer survivorship care during COVID-19-perspectives and recommendations from the MASCC survivorship study group. Support Care Cancer. 2020;28(8):3485-3488.

3. The Lancet Oncology. COVID-19: global consequences for oncology. Lancet Oncol. 2020;21(4):467.

4. Saini KS, de Las Heras B, de Castro J, Venkitaraman R, Poelman M, Srinivasan G, et al. Effect of the COVID-19 pandemic on cancer treatment and research. Lancet Haematol. 2020;7(6):e432-e435.

5. Bray F, Ferlay J, Soerjomataram I, Siegel RL, Torre LA, Jemal A. Global cancer statistics 2018: GLOBOCAN estimates of incidence and mortality worldwide for 36 cancers in 185 countries. CA Cancer J Clin. 2018;68(6): 394-424.

6. International Agency for Research on Cancer (IARC) (2018) Colorectal cancer. https://gco.iarc.fr/today/data/factsheets/cancers/10_8_9-Colorectumfact -sheet.pdf.

7. Vekic B, Dragojevic-Simic V, Jakovljevic M, Pilipovic F, Simic R, Zivic R, et al. Medical Cost of Colorectal Cancer Services in Serbia Between 2014 and 2017: National Data Report. Front Pharmacol. 2019;10:526.

8. Maringe C, Spicer J, Morris M, Purushotham A, Nolte E, Sullivan R, et al. The impact of the COVID -19 on the cancer deaths due to delays in diagnosis in England, UK: national population based, modelling stady. Lancet Oncol. 2020;21(8):1023-1034.

9. Hanna TP, King WD, Thibodeau S, Jalink M, Paulin GA, Harvey-Jones E, et al. Mortality due to cancer treatment delay: systematic review and metaanalysis. BMJ 2020;371:m4087.

10. O'Leary MP, Choong KC, Thornblade LW, Fakih MG, Fong Y, Kaiser AM. Management Considerations for the Surgical Treatment of Colorectal Cancer During the Global Covid-19 Pandemic. Ann Surg. 2020;272(2):e98-e105.

11. Flemming JA, Nanji S, Wei X, Webber C, Groome P, Booth CM. Assotiation between time to suregry et survival among patients with colon cancer: a population - based stady. Eur J Surg Oncol. 2017;43(8):1447-1455.

12. Morris EJA, Goldacre R, Spata E, Mafham M, Finan PJ, Shelton J, et al. Impact of the COVID-19 pandemic on the detection and management of colorectal cancer in England: a population-based study. Lancet Gastroenterol Hepatol. 2021;6(3):199-208.

13. Lei S, Jiang F, Su W, Chen C, Chen J, Mei W, et al. Clinical characteristics and outcomes of patients undergoing surgeries during the incubation period of COVID-19 infection. E Clinical Medicine. 2020;21:100331.

14. Cui J, Li Z, An Q, Xiao G. Impact of the COVID-19 Pandemic on Elective Surgery for Colorectal Cancer. J Gastrointest Cancer. 2021;1-7.

15. Choi JY, Park IJ, Lee HG, Cho E, Kim YI, Kim CW, et al. Impact of the COVID-19 Pandemic on Surgical Treatment Patterns for Colorectal Cancer in a Tertiary Medical Facility in Korea. Cancers. 2021;13(9):2221.

16. Coccolini F, Tartaglia D, Puglisi A, Giordano C, Pistello M, Lodato M, et al. SARS-Co-V2 present in peritoneal fluid in COVID-19 patients. Ann Surg 2020;272:e240-e242.

17. El Boghdady M, Ewalds-Kvist BM. Laparoscopic Surgery and the debate on its safety during COVID-19 pandemic: A systematic review of recommendations. Surgeon. 2021;19(2):e29-e39.

18. Liang W, Guan W, Chen R, Wang W, Li J, Xu K, et al. Cancer patient in SARS-CoV-2 infection: a nationwide analysis in China. Lancet Oncol. 2020; 21(3):335-337.

19. Wang H, Zhang L. Risk of COVID-19 for patient with cancer. Lancet Oncol. 2020;21(4):e181.

20. Allaix ME, Lo Secco G, Velluti F, De Paolis P, Arolfo S, Morino M. Colorectal surgery during the COVID-19 outbreak: do we need to change? Updates Surg. 2021;73(1):173-177

21. Xu Y, Huang ZH, Zheng CZ, Li C, Zhang YQ, Guo TA, et al. The impact of COVID-19 pandemic on colorectal cancer patients: a single-center retrospective study. BMC Gastroenterol. 2021;21(1):185.

22. Tevis SE, Kennedy GD. Postoperative Complications: Looking Forward to a Safer Future. Clin Colon Rectal Surg. 2016;29(3):246-52.

23. Mik M, Magdzinska J, Dziki L, Tchorzewski M, Trzcinski R, Dziki A. Relaparotomy in colorectal cancer surgery- Do any factors influence the risk of mortality? A case controlled stady. Int J Surg. 2014;12(11):1192-7.

24. Aguiar S, Riechelmann RP, de Mello CAL, da Silva JCF, Diogenes IDC, Andrade MS, et al. Impact of COVID-19 on colorectal cancer presentation. Br J Surg. 2021;108(2):e81-e82. 